Jurnal Psikologi Pendidikan \& Konseling: Jurnal Kajian Psikologi Pendidikan dan Bimbingan Konseling

Volume 5 Nomor 2 Desember 2019. Hal 104-111

p-ISSN: 2443-2202 \& e-ISSN: 2477-2518

Homepage: http://ojs.unm.ac.id/index.php/JPPK

DOI: https://doi.org/10.26858/jppk.v5i2.10930

\title{
Self-efficacy, academic motivation, self-regulated learning and academic achievement
}

\author{
Mehmed, S.W. Alafghani \\ Psychology, Universitas Muhammadiyah Surakarta, Indonesia \\ Email: medmedafghani01@gmail.com \\ Eny Purwandari \\ Psychology, Universitas Muhammadiyah Surakarta, Indonesia \\ Email: eny.purwandari@ums.ac.id
}

(Received: 10-September-2019; Reviewed: 10-November-2019; Accepted: 22-December-2019; published: 27-December-2019)

\begin{abstract}
This study aims to empirically prove that the relationship between selfefficacy, academic motivation, self-regulated learning and academic achievement. In addition, empirically proved the mediating role of self-regulated learning on self-efficacy, academic motivation and student achievement. This study used quantitative expansive method. The sample of this study was 246 students of an Islamic senior high school recruited using census technique; thus, the entire population was used as the sample of the study. Data were collected using a questionnaire and were analyzed using Structural Equation Model (SEM). The results empirically show that there is a relationship between self-efficacy, academic motivation, self-regulated learning and academic achievement. However, there is no relationship between self-regulated learning and academic achievement.
\end{abstract}

Keywords: Self-efficacy; motivation; self-regulated learning; achievement; academic.

Abstrak: Penelitian ini bertujuan untuk membuktikan secara empiris hubungan efikasidiri dan motivasi akademik dengan pengaturan belajar mandiri dan prestasi akademik. Selain itu, membuktikan secara empiris peran mediasi pengaturan belajar mandiri antara efikasi-diri dan motivasi akademik dengan prestasi akademik siswa. Metode yang digunakan dalam penelitian adalah metode ekspanatif kuantitatif. Sample penelitian ini adalah 246 siswa Sekolah Madrasah Aliyah Negeri Surakarta. Pengambilan sampel dalam penelitian ini adalah dengan teknik sensus yakni seluruh populasi dijadikan sampel. Pengumpulan data menggunakan kuesioner. Data dianalisis dengan menggunakan Structural Equation Model (SEM). Hasil penelitian menunjukkan bahwa secara empiris ada hubungan antara efikasi-diri dan motivasi akademik dengan pengaturan belajar mandiri dan prestasi akademik. Tidak ada hubungan antara pengaturan belajar mandiri dengan prestasi akademik.

Kata Kunci: Efikasi-diri; motivasi; pengaturan belajar mandiri; prestasi; akademik. 


\section{INTRODUCTION}

Student academic achievement reflects the accomplishments of a country's educational goals because it refers to the extent to which students master the lessons represented by student learning outcomes. Academic achievement indicates the learning success (Eva, 2018). A study by Zahra \& Hernawati (2015) revealed that academic achievement of Indonesian students was still low. Many factors contribute to low student achievement. Research has shown that academic achievement in the world of education is a multidimensional consequence of the relationship students have with families, communities, schools, and peers (Lucio, Rapp-Paglicci \& Rowe, 2011).

The overlap between expectations and realities signifies that there is a gap caused by factors related with parents (family causative factors), teachers (academic causative factors), and students (personal causative factors, e.g. socal attitudes). Although the combination of these factors affect student achievement, individual characteristics such as prior academic achievement, self-efficacy or learning motivation, skills and attitudes have been identified to correlate with learning achievement. In addition, socio-economic background with specific references with parental education has been shown to have a positive influence on student learning achievement (Amponsah, Milledzi, Ampofo \& Gyambrah, 2018).

Previous studies have suggested that academic achievement positively correlates with several variables such as self-efficacy, academic motivation, and self-regulated learning. Academic motivation is defined as motivation that initiates and guides students to have more interests in learning (Lavasani, Mirhosseini, Hejazi, \& Davoodi, 2011). A study by Agustiani, Cahyad \& Musa (2016) showed that self-efficacy and academic achievement have a positive correlation. Students with higher level of self-efficacy can complete assignments more successfully and have better performance because high self-confidence can result in high level of energy put into a task. This is in line with the results of the study by Yusuf (2011) that self-efficacy has a significant positive influence on Cummulative Grade Point Average (CGPA).

A study by Vecchione, Alessandri \& Marsicano (2014) revealed that academic achievement has a favorable association with academic motivation, meaning that students with high academic motivation are able to improve their academic achievement. This is in parallel with the study by Mega, Ronconi \& De Beni (2014) suggesting that there is a positive relationship between motivation and academic achievement. Academic achievement is the driving force that guides students to pursue goals and overcome obstacles. Students with high level of self-confidence will strive and not easily give up when encountering difficulties. This corresponds with a study by Wurf \& CroftPiggin (2015) showing that there is positive correlation between academic achievement and motivation.

Self-regulated learning is one of the significant predictors of academic achievement. The more self-regulated learning is used, the higher students' academic achievement is. Selfregulated learning creates opportunities for students to manage resources and to perform better in all learning processes (Agustiani, Cahyad, \& Musa, 2016; Banarjee \& Kumar, 2014).

The results of studies by Akbay \& Akbay (2016); Banarjee \& Kumar (2014); Agustiani, Cahyad \& Musa (2016) found that there is a significant positive correlation between selfregulated learning and academic achievement. Research has also shown that self-efficacy has a significant positive relationship with selfregulated learning (Bravo, 2014; Cerezo et al., 2018; Cleary \& Kitsantas, 2017). Academic motivation has a significant positive association with self-regulated learning (Akbay \& Akbay, 2016; Mahmoodi, Kalantari \& Ghaslanic, 2014). According to Zimmerman (2012) an individual who has a high level of self-regulated learning can motivate and lead himself or herself towards goals, meaning that students with higher selfefficacy are more prepared to do more difficult and challenging tasks and strive to maintain attitudes towards objectives than students with lower self-efficacy are.

Higher self-efficacy, academic motivation and self-regulated learning are expected to improve student academic achievement. Additionally, self-efficacy and academic motivation are likely to encourage selfregulation for independent learning. This study aims to empirically prove that 1) self-efficacy, academic motivation and self-regulated learning affect academic achievement, and 2) self- 
efficacy and academic motivation influence students' self-regulated learning.

A study by Jagad \& Khairunnina (2018) showed that there is a relationship between selfefficacy and self-regulated learning. The higher the level of students' self-efficacy, the higher the level of students' self regulated learning. This study focused only on the relationship between self-efficacy and self-regulated learning. The present study, however, investigates not only the link between selfefficacy and self-regulated learning, but also the relationship between self-efficacy, academic motivation, self-regulated learning, academic achievement.

\section{METHODS}

The population of this expansive study was 246 students of Madrasah Aliyah Negeri (MAN) 2 in Surakarta in the odd semester of the 2019/2020 academic year. All students in the tenth grade were recruited using census sampling technique, meaning that all the population became the sample of the study.

The population of this expansive study was 246 students of Madrasah Aliyah Negeri (MAN) 2 in Surakarta in the odd semester of the 2019/2020 academic year. All students in the tenth grade were recruited using census sampling technique, meaning that all the population became the sample of the study.

Content validity with expert judgment technique was used as the research instrument. The results of the professional judgment assessment were analyzed using Ms. Excel and Aiken formula. Based on the calculation results of the Self-Efficacy Scale with Aiken formula, a total of 34 items were worth testing for this study. Analysis technique used in this study was Structural Equation Modeling (SEM) using the AMOS software.

\section{RESULTS AND DISCUSSION}

The results of hypothesis testing are presented in Table 1.

Table 1. Hypothesis Testing

\begin{tabular}{lllrrc}
\hline & & & C.R. & P & Keterangan \\
\hline SRL & $<---$ & Self-Efficacy & 3.341 & $* * *$ & Significant \\
SRL & $<---$ & Academic Motivation & 4.908 & $* * *$ & Significant \\
Academic Achievement & $<---$ & Self-Efficacy & -2.205 & .027 & Significant \\
Academic Achievement & $<---$ & Academic Motivation & 2.840 & .005 & Significant \\
Academic Achievement & $<---$ & SRL & -.994 & .320 & Insignificant \\
\hline
\end{tabular}

Figure 1. Modification Results of Structural Modeling Estimates

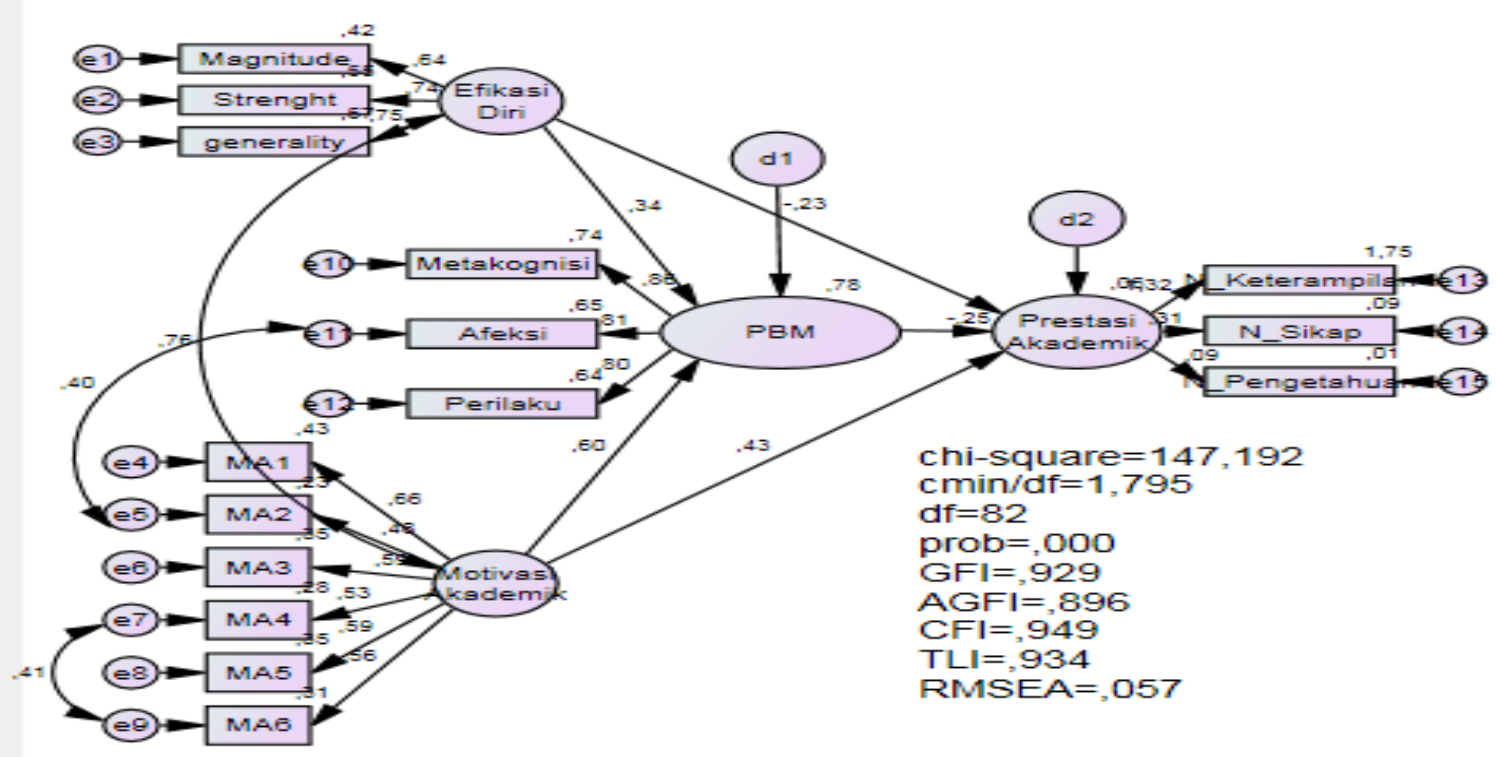


Test on ediation effect aims to detect the position of mediating variables in a model. The nature of the mediating variables is examined by comparing the values of Standardized Direct
Effects and Standardized Indirect Effects from the AMOS software output summarized in the following table.

Table 2. Results of Tests on Direct and Indirect Effects

\begin{tabular}{ccccc}
\hline $\begin{array}{c}\text { Direct } \\
\text { Effects }\end{array}$ & $\begin{array}{c}\text { Academic } \\
\text { Motivation }\end{array}$ & Self-Efficacy & SRL & $\begin{array}{c}\text { Academic } \\
\text { Achievement }\end{array}$ \\
\hline $\begin{array}{c}\text { SRL } \\
\text { Academic }\end{array}$ & 0.585 & 0.354 & 0.000 & 0.000 \\
Achievement & 0.800 & -0.435 & -0.320 & 0.000 \\
\hline Indirect & & & \\
Effects & 0.000 & 0.000 & 0.000 & 0.000 \\
\hline $\begin{array}{c}\text { SRL } \\
\text { Academic }\end{array}$ & -0.187 & -0.114 & 0.000 & 0.000 \\
Achievement & & & & \\
\hline
\end{tabular}

Based on the results of analysis using SEM analysis technique, the Square Multiple Correlation value of the self-regulated learning variable was 0.733 showing that self-efficacy and academic motivation contributed to selfregulated learning of $77.3 \%$, while the remaining $2.7 \%$ was influenced by other factors outside the independent variable. This result signifies that students with high levels of selfefficacy and academic motivation have selfregulated learning. Besides, the Square Multiple Correlation value of academic achievement variable was 0.204 showing that self-efficacy, academic motivation and self-regulated learning gave $20.4 \%$ of contribution to academic achievement, while the remaining $79.6 \%$ was influenced by other factors outside the variables under the study. This result indicates that students with high levels of self-efficacy, academic motivation and self-regulated learning can improve their academic achievement. Therefore, the major hypothesis that there is a relationship between self-efficacy, academic motivation, self-regulated learning and student academic achievement is accepted.

The minor hypothesis states that there is a significant relationship between variables of self-efficacy and self-regulated learning. Selfefficacy is an individual's confidence and ability to complete a particular task. In other words, self-efficacy is an ability to manage and control behaviors (Agustiani, Cahyad \& Musa, 2016). According to Agustiani, Cahyad \& Musa (2016), self-efficacy affects feelings, thoughts, motivation and individual behaviors. This means that one's inner beliefs influence personal capabilities and decisions. In reference to academic, self-efficacy has an impact on students' choices of activities, efforts and performance levels.

Students with higher self-efficacy are able to set their learning goals compared with students with lower self-efficacy. Agustiani, Cahyad \& Musa (2016) found in their study that self-efficacy can be utilized to predict the use of self-regulated learning as one of the teaching and learning strategies. Students with high selfefficacy are more likely to use self-regulated learning in more diverse ways to facilitate their learning than those with low self-efficacy. The present study supports previous studies that found self-efficacy has signifcantly favorable association with self-regulated learning (Bravo, 2014; Cerezo et al., 2018; Cleary \& Kitsantas, 2017).

The results of hypothesis testing demonstrate that there is a link between selfefficacy, academic motivation, self-regulated learning and academic achievement. Students with high self-efficacy, academic motivation and self-regulated learning are able to improve academic achievement. Additionally, highly self-efficacious and academic-motivated students adopt self-regulated learning. However, self-efficacy and academic achievement can also have a negative relationship if students are overconfident or under confident in their capabilities. The link between academic motivation and academic achievement is significantly positive, signifying that high academic motivation can reinforce students to become academic achievers.

The results of the present study favor previous studies by Akbay \& Akbay (2016); Mahmoodi, Kalantari, \& Ghaslanic (2014) that found that academic motivation is positively 


\section{8 | Jurnal Psikologi Pendidikan \& Konseling Vol. 5 No. 2 Desember 2019}

linked to self-regulated learning. Self-regulation training can help improve student competitiveness (Sawitri \& Ariati, 2011) even for students who are at risk. During interventions, students have motivational beliefs that help them regulate themselves; for instance, students feel that the the training is interesting, that they need this training, then they need each other; thus, they are willing to contribute (Boekarts, 2010).

Leon, Nunez, \& Liew (2015) state that the more students think about and process the learned information the more students understand and remember it. Thus, students are encouraged to become independent learners and critical thinkers.

The results of another hypothesis testing found that there is a significant, but negative relationship between self-efficacy and academic motivation that is the higher self-efficacy, the lower academic achievement. This result does not correspond with the studies by Agustiani, Cahyad \& Musa (2016); Yusuf (2011) that found that there was a positive correlation between self-efficacy and academic achievement.

The present study found that the negative relationship indicated that students are overconfident or under confident. A study by Sanchez \& Dunning (2018) found that wrong understanding can result in excessive confidence, which in turn can make students more vulnerable to making mistakes. Under confidence, however, can cause students to feel worries, which in turn can push them to violate norms in order to become academic achievers. This is because the research subject was still 1617 years old, meaning that students were still in the middle adolescence stage. Confidence affects teenagers' development in self-identity formation. Failure at this stage can cause role confusion and obstacles in the next stage development (Keliat, Daulima \& Farida, 2011).

The results of another hypothesis testing suggest that there is a significant relationship between academic motivation and academic achievment. Slameto (2010) states that psychological factors play an important role in students' success in becoming academic achievers; one of the factors is motivation. Herawati \& Widiastuti (2013) found in their study that motivation has greater contribution than other variables to academic achievement of the eleventh graders of social studies at SMA Negeri 1 Malang.
Results of other studies demonstrated that academic motivation positively correlates with academic motivation, meaning that the higher academic motivation, the higher academic achievement. On the other hand, it is also found that the lower academic motivation, the lower academic achievement (Lee et al., 2012; Mega, Ronconi \& De Beni, 2014; Vecchione, Alessandri \& Marsicano, 2014; Wurf \& CroftPiggin, 2015). Other studies, however, have shown that academic motivation has no link to self-regulated learning and academic achievement. This finding shows that the high or low self-regulated learning levels cannot improve academic achievement.

According to Zimmerman (2012) selfregulation is not particularly an academic ability, but rather an individual ability to regulate independent learning process through planning, organizing and achieving goals. Selfregulated learning consists of metacognition, motivation, and planned actions cyclically adapted to attain personal objectives. In other words, self-regulated learning is affected by several factors such as personal, behavioral, and environmental factors. Such conditions cause self-regulated learning to have no effect on academic achievement. Furthermore, Zimmerman (2012) explains that self-regulated learning is a self-directed process and selfconfidence that can help students enhance their mental abilities such as verbal skills and their academic performances such as a writing skill. Zimmerman (2012) argues that self-regulated learning is more proactive, not reactive. Students deliberately attempt to acquire learning skills such as setting goals, choosing and implementing strategies, as well as monitoring the effectiveness of the strategies. Self-regulated learning do not instantly happen due to external factors. Self-regulated learning is extremely important when students perform independent learning activities such as discovery learning, reading, or searching for information from electronic sources.

A research by Wibowo (2018) found the role of self-regulated learning and learning motivation on students' mathematics learning achievement. According to Maisaroh (2015), poor self-confidence is likely to influence selfregulated learning. Students with poor selfconfidence are more likely to depend on others in learning. They cannot manage themselves to study independently and have low efforts to succeed, which in turn affect academic 
achievement. This is because self-regulated learning refers to the student's ability to manage his or her own learning without being dependent on others. Poor self-regulated learning is regarded as one of the factors that weaken students' learning process quality. Highly independent students are able to manage their own learning processes, completing tasks and homework without depending on teachers, parents or friends. They are consciously independent in learning because they aim for higher achievement. Conversely, poorly independent students always depend on others when learning; thus, they cannot attain optimum academic achievement. In daily learning activities, students with low self-regulated learning learn a subject matter less optimally, cram the night to study or study the night before examination, depend on friends when completing assignments by lecturers, and cheat on the test. Students with poor self-regulated learning tend to put small efforts towards learning achievement.

The result of the present study is in line with the study by Maisaroh (2015). She found that the better self-regulated learning and selfefficacy students have, the higher academic achievement students earn. The present study, however, found that besides self-regulated learning and self-efficacy, academic motivation can also contribute to academic achievement.

Based on the previous studies, it can be concluded that compared to self-efficacy, selfregulated learning has a minor contribution to student academic achievement. This finding means that students with higher self-confidence, supported with a decent understanding and a proper learning strategy, will become better academic achievers than students only with a good understanding and a proper learning strategy. Students' abilities to plan their own learning strategies and to manage a conducive environment will be able to improve their academic achievement. Likewise, highly selfconfident students, enhanced by the ability to hone their skills to create accurate learning strategies, will intensify their efforts to become better academic achievers.

\section{CONCLUSION AND SUGGESTION}

This study concludes that there is a relationship between self-efficacy, academic motivation, self-regulated learning, and academic achievement of MAN students.
Students with high self-efficacy, academic motivation and self-regulated learning can improve their academic achievement. Regarding the relationship between self-efficacy, academic motivation and self-regulated learning, students with high self-efficacy and academic motivation can manage self-regulated learning. However, a negative relationship is observed between selfefficacy and academic achievement. This relationship can occur because students are overconfident and under confident in their abilities. The association between academic motivation and academic achievement is significantly positive, signifying that high academic motivation can encourage students to become academic achievers. Another finding suggests that self-regulated learning plays a role in mediating between academic motivation and academic achievement.

Recommendations are given as a followup study. First, teachers are suggested designing a teaching and learning process that allows students to develop their learning strategies. Besides, teachers also need to encourage students to boost their self-confidence and academic achievement by giving rewards to the achievers in the class. Second, guidance counselors are recommended assisting students in dealing with overconfidence and under confidence so that students are able to choose, prepare themselves, take on responsibilities and gain values when making decisions, such as utilizing group work. Third, researchers interested in academic achievement can use this study as a reference.

Some limitations of the present study should be noted. The participants of the study were only the students of one Islamic high school, namely MAN 2 Surakarta; thus, it is difficult to generalize the findings to all students in Indonesia. Moreover, this study did not gather more information about students' abilities from parents or teachers.

\section{REFERENCES}

Agustiani, H., Cahyad, S., \& Musa, M. (2016). Efikasi-diri and Self-Regulated Learning as Predictors of Students Academic Performance. The Open Psychology Journal, No. 9. Hal 1-6.

Akbay, T., \& Akbay, L. (2016). On the Causal Relationships Between Academic Achievment and Its Leading Factors: A 
110 | Jurnal Psikologi Pendidikan \& Konseling Vol. 5 No. 2 Desember 2019

sem Study. Journal of European Education, Vol 6, No. 2.

Amponsah, M., Milledzi, E.Y, Ampofo, E.T., , \& Gyambrah M. . (2018). Relationship between Parental Involvement and Academic Performance of Senior High School Students: The Case of Ashanti Mampong Municipality of Ghana. American Journal of Educational Research, Vol 6, No 1.

Banarjee, P., \& Kumar, K. (2014). A Study on Self-Regulated Learning and Academic Achievment Among The Science Graduate Students. International Journal of Multidisciplinary Approach and Studies, Vol 1, No 6.

Boekarts, M. (2010). The crucial role of motivation and emotion in classroom learning. The Nature of Learning : Using research to inspire practice.

Bravo, A. A. (2014). Academic Self-Efficacy, Self-Regulated Learning and Academic Performance in First-Year Uinversity Students. Propositos y Representaciones Revista de Psicologia Educativa de La USIL, Vol 2. No 1, Hal 101-120.

Cerezo, R., Fernandez, E., Amieiro, N., Valle, A., Rosario, P., \& Nunez, J.C. (2018). Mediating Role of Efikasi-Diri and Usefulness Between Self-Regulated Learning Strategy Knowledge and Its Use. Revista de Psicodidactica, Vol 24, No 1, Hal 1-8.

Cleary, T., \& Kitsantas A. (2017). Motivation and Self-Regulated Learning Influences on Middle School Mathematics Achievment. School Psychology Review, Vol 46, No. 1. Hal 88-107.

Eva, N. (2018). Determinan Pretasi Akademik Ilmu Pengetahuan Alam (IPA) Siswa Cerdas Istimewa dengan Self-Regulated Learning sebagai Mediator. Universitas Airlangga.

Herawati, I., \& Widiastuti, Y. (2013). Analisis Faktor-faktor yang Mempengaruhi Prestasi Belajar Akuntansi. Journal of Accounting and Business Education, Vol 1, No. 3 .

Jagad, H., K., M., \& Khairunnina, R., N. (2018). Hubungan Antara Efikasi Diri dengan Self Regulated Learning Pada Siswa SMPN X. Jurnal Penelitian Psikologi, Vol 5, No 3.
Keliat, B., Daulima, N.H.C, \& Farida, P. (2011). Manajemen keperawatan psikososial \& kader kesehatan jiwa CMHN (intermediate course). Jakarta: EGC.

Lavasani, M., Mirhosseini, F.S., Hejazi, H., \& Davoodi, M. (2011). The Effect of SelfRegulation Learning Strategies Training on The Academic Motivation and Efikasi-Diri. Procedia-Social and Behavioral Sciences, Vol 29. Hal 627632.

Lee, N., Krabbendam, L., Dekker, S., Boschloo, A., De Groot, Renate, H.M, \& Jolles, J. (2012). Academic Motivation Mediates the Influence of Temporal Discounting on Academic Achievment During Adolences. Trends in Neurosciences and Education, Vol 1, Hal 43-48.

Leon, J., Nunez, J., \& Liew, J. (2015). SelfDetermination and STEM Education: Effects of Autonomy, Motivation, and Self-Regulated Learning on High School Math Achievment. Learning and Individual Differences.

Lucio, R., Rapp-Paglicci, L., \& Rowe, W. (2011). Developing an additive risk model for predicting academic index: School factors and academic achievement. . Child AdolescSoc Work, Vol 28.

Mahmoodi, M., Kalantari, B., \& Ghaslanic, R. (2014). Self-Regulated Learning (SRL), Motivation and Languange Achievment of Iranian EFL Learners. ProcediaSocial and Behavioral Sciences, Vol. 98, No. 1062-1068.

Maisaroh. (2015). Pengaruh Self Efficacy dan Self Regulated Learning Terhadap Prestasi Belajar pada Mahasiswa Fakultas Ekonomi Universitas Negeri Jakarta. Journal \& Proceeding FEB Unsoed, Vol 5, No 1.

Mega, C., Ronconi, L., \& De Beni, R. (2014). What Makes a Good Student? How Emotions, Self-Regulated Learning, and Motivation Contribute to Academic Achievment. Journal of Educational Psychology, Vol 106, No. 1, Hal 121131.

Sanchez, C., \& Dunning, D. (2018). Learning a Little About Something Makes Us Overconfident. Harvard Business Review.

Sawitri, D. R, \& Ariati, J. (2011). Self Regulation Training as an Effort to 
echance Students Competitiveness. Jakarta: Paper Presented in The International Conference on Psychology of Resilience.

Slameto. (2010). Belajar dan Faktor yang Mempengaruhi. Jakarta: Rineka Cipta.

Vecchione, M., Alessandri, G., \& Marsicano, G. (2014). Academic Motivation Predicts Educational Attainment: Does Gender Make A Difference? . Learning and Individual Differences, No 32. Hal 124131.

Wibowo, D. E. (2018). Peran Sef Regulated Learning dan Motivasi Belajar Terhadap Prestasi Belajar Matematika Siswa yang Sering Mengikuti Lomba Ekestrakurikuler Olahraga Sekolah . Jurnal Mitra Pendidikan, Vol 2 No. 9.

Wurf, G., \& Croft-Piggin, L. (2015). Predicting The Academic Achievment of FirstYear, Pre-Service Teachres: The Role of Engagement, Motivation, ATAR, and Emotional Intelligence. Asia-Pacific Journal of Teachers Education, Vol. 43, No 1, Hal 75-91.
Yusuf, M. (2011). The Impact of Efikasi-Diri, Achievment Motivation, and Self Regulated Learning Strategies on Students' Academic Achievment . Procedia Social and Behavioral Sciences, Vol 15.

Zahra, Y., \& Hernawati, N. (2015). Prokrastinasi Akademik Menghambat Peningkatan Prestasi Akademik Remaja di Wilayah Pedesaan Yuana. Jurnal Ilmu Keluarga dan Konsumen, Vol 8, No 3, Hal 163-172.

Zimmerman, B. J. (2012). Goal setting: A key proactive source of academic selfregulation. New York, NY: Routledge Taylor \& Francis Group. 